\title{
WIND PROGRAM
}

\section{Federal Incentives for Wind Power}

The U.S. Department of Energy's

(DOE's) Wind Program works

to accelerate the deployment

of wind power. This document

lists some of the major federal

incentives for wind power. This

list is current as of April 2013.

\section{Research and Development (R\&D) Grants}

The DOE Wind Program periodically posts competitive solicitations for $R \& D$ grants to improve the performance and lower the cost of wind energy, or to reduce barriers to deployment. wind.energy.gov/ financial_opportunities.htm/

DOE's Advanced Research Projects Agency-Energy (ARPA-E) sponsors R\&D grants for earlier-stage, highpotential, high-impact energy technologies. arpa-e.energy. gov/?q=programs/apply-for-funding

DOE's Small Business Innovation Research and Small Business Technology Transfer (SBIR/STTR) Program offers periodic solicitations for small businesses. science.energy. gov/sbir/funding-opportunities/

While DOE's R\&D Programs generally do not fund the purchase or installation of wind energy systems by individuals or companies, there are a number of governmentsponsored deployment incentives as outlined in this publication.

Additional resources for information on financial incentives:

DOE's Office of Energy Efficiency and Renewable Energy eere.energy. gov/financing/consumers.htm/

Database of State Incentives for Renewable Energy dsireusa.org

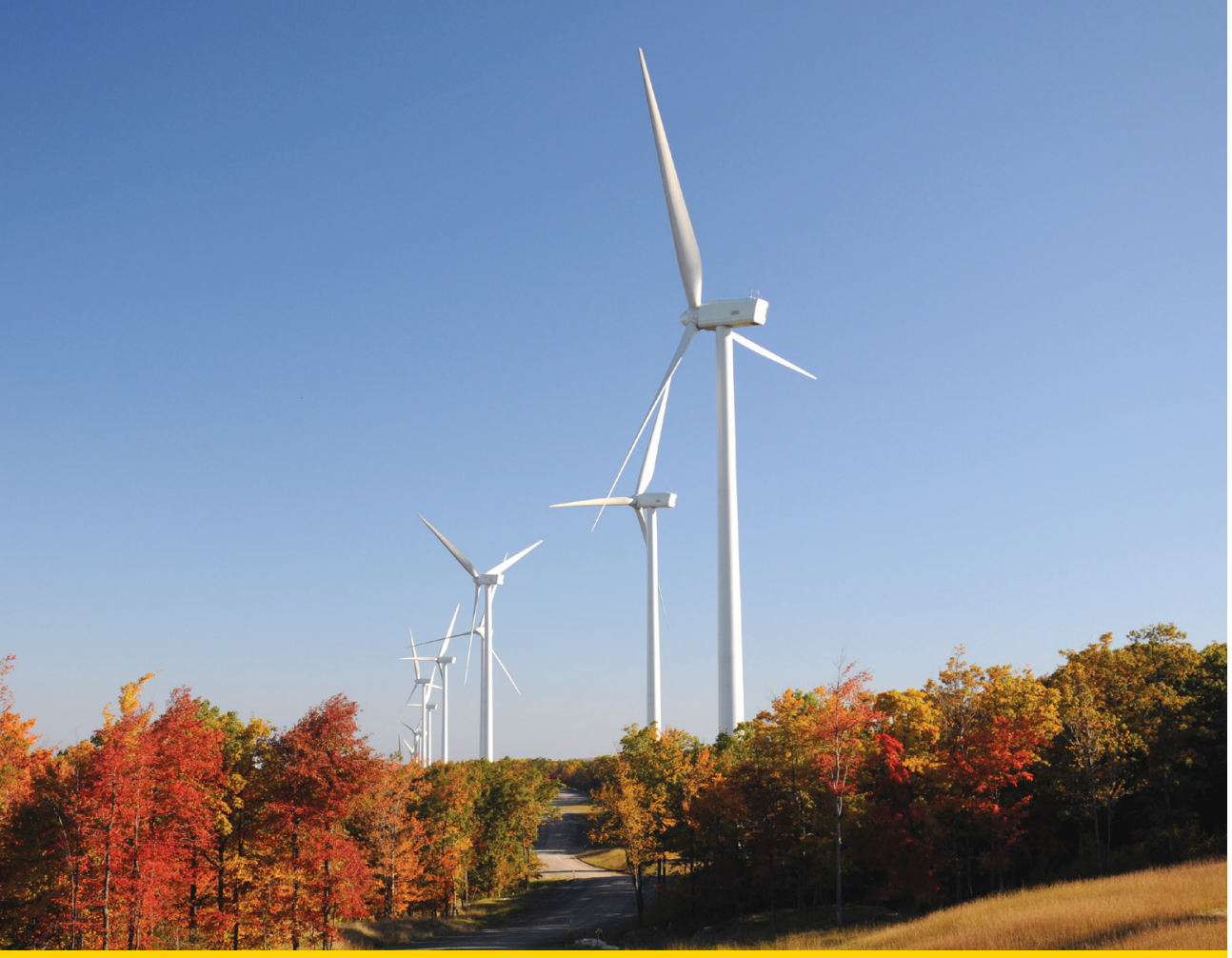

By the end of 2012, the United States had 60,007 MW of installed wind capacity. Photo from Moe Vetter, NREL 16204

\section{Tax Incentives}

The federal government uses several tax-based policy incentives to stimulate the deployment of renewable energy. The Department of the Treasury's Internal Revenue Service (IRS) administers these incentives.

\section{The federal Renewable Electricity} Production Tax Credit (PTC), established by the Energy Policy Act of 1992, allows owners of qualified renewable energy facilities to receive tax credits for each kilowatt-hour ( $\mathrm{kWh}$ ) of electricity generated by the facility over a 10 -year period. Qualified wind power projects are eligible to receive 2.3 cents per $\mathrm{kWh}$ for the production of electricity from utility-scale wind turbines (indexed for inflation). dsireusa.org/incentives/incentive. cfm? Incentive_Code=US13F

The federal Business Energy Investment Tax Credit (ITC) is a corporate tax incentive that allows for owners of new wind energy systems of any size to receive tax credits worth $30 \%$ of the value of the facility. dsireusa.org/ incentives/incentivecfm? Incentive Code $=$ USO2F

Project owners must choose between the one-time Investment Tax Credit, tied to the total value of the facility, and the Production Tax Credit, tied to the energy produced over a 10 -year period. To qualify for either the PTC or the ITC, these projects must begin construction by December 31, 2013, which is defined as starting physical work of a significant nature or incurring $5 \%$ of the total project cost. irs.gov/pub/irs-drop/n-13-29.pdf

Commercial owners of small wind turbines (100 kW or less) placed in service prior to December 31, 2016 are also eligible for the ITC.

Homeowners who purchase and install a qualifying residential small wind electric system (100 kW or less) 
by December 31, 2016 may claim the Residential Renewable Energy Tax Credit. This credit is worth $30 \%$ of the value of the system with no upper limit. dsireusa.org/incentives/ incentive.cfm?/ncentive_Code=US37F

The Advanced Energy Manufacturing Tax Credit (commonly referred to as 48C), established by the Recovery Act, supports investment in domestic clean energy and energy efficiency manufacturing facilities through a competitivelyawarded 30\% investment tax credit. Concept papers are due April 9, 2013, and projects will be assessed by DOE based on the following criteria: commercial viability, domestic job creation, technological innovation, speed to project completion, and potential for reducing air pollution and greenhouse gas emissions. energy.gov/downloads/ fact-sheet-48c-manufacturing-tax-credits

\section{The Modified Accelerated Cost-} Recovery System (MACRS) allows businesses to recover investments in certain renewable energy property, including small wind (100 kW or less), through depreciation deductions over a 5-year period following purchase. The American Taxpayer Relief Act of 2012 extended the deadline for the $50 \%$ first-year bonus depreciation to December 31, 2013. dsireusa.org/incentives/incentive. cfm?Incentive_Code=USO6F

\section{Incentives for Tax-Exempt Entities}

Several incentives are available to stimulate the deployment of wind power by certain tax-exempt entities that cannot take advantage of tax credits.

\section{Qualified Energy Conservation Bonds} (QECBs) allow qualified state, tribal and local government issuers to borrow money at attractive rates to fund energy efficiency and renewable energy projects. A QECB is among the lowest-cost public financing tools because the U.S. Department of Treasury subsidizes the issuer's borrowing costs. Issuers may choose between structuring QECBs as tax credit bonds or as direct subsidy bonds. Both tax credit and direct payment bonds subsidize borrowing costs - most QECBs are expected to be issued as direct subsidy bonds due to the current lack of investor appetite for tax credit bonds. QECB proceeds can be used to fund capital expenditures on wind power projects that spur rural development. irs.gov/pub/ irs-drop/n-09-29.pdf

In addition, DOE's Tribal Energy

Program provides financial and technical assistance, education and training to tribes for the evaluation and development of renewable energy resources on tribal lands. eere.energy. gov/tribalenergy

\section{Other Deployment Incentives}

DOE offers loan guarantees to help companies secure financing to deploy innovative, clean energy technologies that reduce, avoid or sequester carbon dioxide and other emissions. The Recovery Act provides a new, temporary addition to the existing program which is aimed at standard renewable projects, including wind power projects. lgprogram.energy.gov

The U.S. Department of Agriculture provides farmers and ranchers with grants for renewable energy development assistance through its Rural Energy for America Program (REAP). Certain entities, such as state, local, and tribal governments, educational institutions, and rural electric cooperatives, are also eligible for these grants. rurdev.usda.gov/energy.htm/
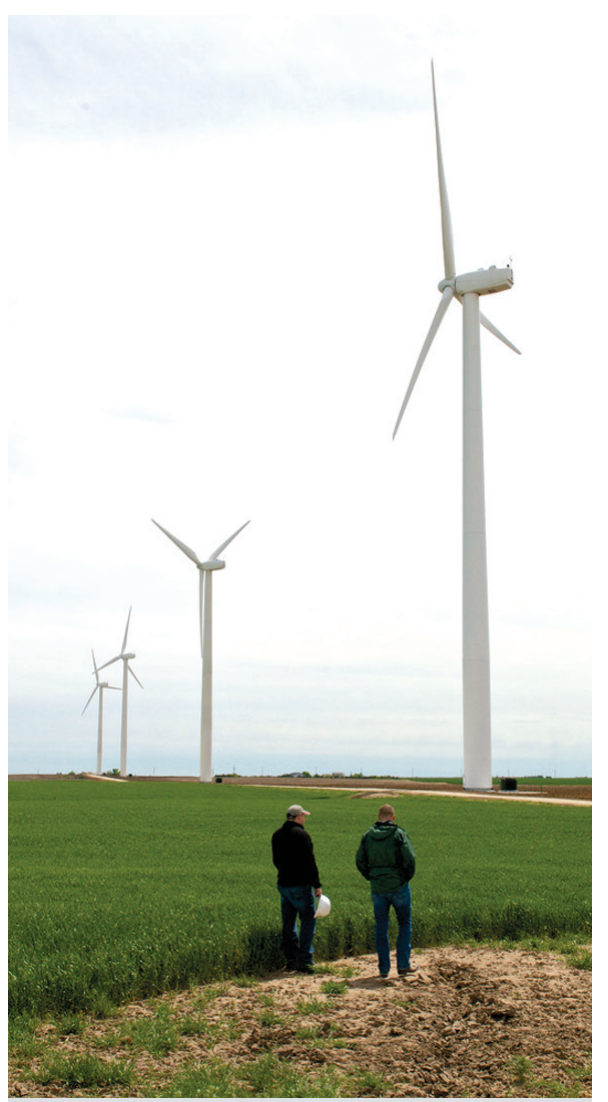

The Department of Agriculture provides grants to farmers and ranchers for renewable energy development. Photo from Native Energy, Inc., NREL 17589 